OPEN ACCESS

Edited by:

Shabir Hussain Wani, SKUAST-Kashmir, India

Reviewed by:

Adriano Sofo,

Università degli Studi della Basilicata,

Bu-Jun Shi,

University of Adelaide, Australia

*Correspondence:

Parvaiz Ahmad parvaizbot@yahoo.com

Specialty section:

This article was submitted to Crop Science and Horticulture, a section of the journal

Frontiers in Plant Science

Received: 24 January 2016

Accepted: 01 April 2016

Published: 27 April 2016

Citation:

Ahmad P, Abdel Latef AA, Abd_Allah EF, Hashem A, Sarwat M, Anjum NA and Gucel S (2016)

Calcium and Potassium Supplementation Enhanced Growth, Osmolyte Secondary Metabolite

Production, and Enzymatic

Antioxidant Machinery in Cadmium-Exposed Chickpea (Cicer arietinum L.). Front. Plant Sci. 7:513. doi: 10.3389/fpls.2016.00513

\section{Calcium and Potassium Supplementation Enhanced Growth, Osmolyte Secondary Metabolite Production, and Enzymatic Antioxidant Machinery in Cadmium-Exposed Chickpea (Cicer arietinum L.)}

\author{
Parvaiz Ahmad ${ }^{1,2 *}$, Arafat A. Abdel Latef ${ }^{3,4}$, Elsayed F. Abd_Allah ${ }^{5}$, Abeer Hashem ${ }^{1,6}$, \\ Maryam Sarwat ${ }^{7}$, Naser A. Anjum ${ }^{8}$ and Salih Gucel ${ }^{9}$
}

${ }^{1}$ Department of Botany and Microbiology, Faculty of Science, King Saud University, Riyadh, Saudi Arabia, ${ }^{2}$ Department of Botany, Sri Pratap College, Srinagar, India, ${ }^{3}$ Botany Department, Faculty of Science, South Valley University, Qena, Egypt, ${ }^{4}$ Biology Department, College of Applied Medical Sciences, Taif University, Taif, Saudi Arabia, ${ }^{5}$ Department of Plant Production, Faculty of Food and Agricultural Sciences, King Saud University, Riyadh, Saudi Arabia, ${ }^{6}$ Mycology and Plant Disease Survey Department, Agriculture Research Center, Plant Pathology Research Institute, Giza, Egypt, ${ }^{7}$ Pharmaceutical Biotechnology, Amity Institute of Pharmacy, Amity University, Uttar Pradesh, India, ${ }^{8}$ Department of Chemistry, Centre for Environmental and Marine Studies, University of Aveiro, Aveiro, Portugal, ${ }^{9}$ Centre for Environmental Research, Near East University, Lefkosa, Cyprus

This work examined the role of exogenously applied calcium (Ca; $50 \mathrm{mM}$ ) and potassium ( $\mathrm{K} ; 10 \mathrm{mM}$ ) (alone and in combination) in alleviating the negative effects of cadmium $(\mathrm{Cd} ; 200 \mu \mathrm{M})$ on growth, biochemical attributes, secondary metabolites and yield of chickpea (Cicer arietinum L.). Cd stress significantly decreased the length and weight (fresh and dry) of shoot and root and yield attributes in terms of number of pods and seed yield (vs. control). Exhibition of decreases in chlorophyll (Chl) $a$, Chl $b$, and total Chl was also observed with Cd-exposure when compared to control. However, Cd-exposure led to an increase in the content of carotenoids. In contrast, the exogenous application of $\mathrm{Ca}$ and $\mathrm{K}$ individually as well as in combination minimized the extent of Cd-impact on previous traits. C. arietinum seedlings subjected to $\mathrm{Cd}$ treatment exhibited increased contents of organic solute (proline, Pro) and total protein; whereas, $\mathrm{Ca}$ and K-supplementation further enhanced the Pro and total protein content. Additionally, compared to control, Cd-exposure also caused elevation in the contents of oxidative stress markers (hydrogen peroxidase, $\mathrm{H}_{2} \mathrm{O}_{2}$; malondialdehyde, MDA) and in the activity of antioxidant defense enzymes (superoxide dismutase, SOD; catalase, CAT; ascorbate peroxidase, APX; glutathione reductase, GR). $\mathrm{Ca}, \mathrm{K}$, and $\mathrm{Ca}+\mathrm{K}$ supplementation caused further enhancements in the activity of these enzymes but significantly decreased contents of $\mathrm{H}_{2} \mathrm{O}_{2}$ and MDA, also that of $\mathrm{Cd}$ accumulation in shoot and root. The contents of total phenol, flavonoid and mineral elements ( $\mathrm{S}, \mathrm{Mn}, \mathrm{Mg}, \mathrm{Ca}$ and $\mathrm{K}$ ) that were also suppressed in 
Cd stressed plants in both shoot and root were restored to appreciable levels with $\mathrm{Ca}$ - and $\mathrm{K}$-supplementation. However, the combination of $\mathrm{Ca}+\mathrm{K}$ supplementation was more effective in bringing the positive response as compared to individual effect of $\mathrm{Ca}$ and $\mathrm{K}$ on $\mathrm{Cd}$-exposed $\mathrm{C}$. arietinum. Overall, this investigation suggests that application of $\mathrm{Ca}$ and/or K can efficiently minimize Cd-toxicity and eventually improve health and yield in $C$. arietinum by the cumulative outcome of the enhanced contents of organic solute, secondary metabolites, mineral elements, and activity of antioxidant defense enzymes.

Keywords: antioxidant enzymes, cadmium toxicity, chickpea, oxidative stress, organic solutes, secondary metabolites, yield attributes

\section{INTRODUCTION}

Cadmium (Cd), a naturally occurring element having no known beneficial role is a highly toxic environmental pollutant (Mobin and Khan, 2007; Shamsi et al., 2008; Asgher et al., 2015). Cd can enter the environment via multiple pathways including atmospheric deposition, wastewater irrigation, phosphatic fertilizers, usage of metal-containing pesticides and many industrial processes (Amirjani, 2012; Abdel Latef, 2013). Plants can easily uptake Cd by roots and transport it to shoots, which eventually cause toxicity there (Talukdar, 2012; Abdel Latef, 2013). Accumulation of $\mathrm{Cd}$ brings complex changes in plants at physiological, biochemical and genetic levels (El-Beltagi and Mohamed, 2013). The most obvious symptoms are: (i) inhibition of seed germination and suppression of plant growth (Siddique et al., 2012; Abdel Latef, 2013), (ii) degeneration of chlorophyll (Chl) synthesis and disturbance in Calvin cycle enzymes leading to decrease in photosynthesis (Mobin and Khan, 2007; Shamsi et al., 2008), and (iii) induction of stomatal closure due to its effect on the water balance of the plant (Perfus-Barbeoch et al., 2002). Additionally, tissue/organ-Cd-burden can alter carbohydrates, proline (Pro) and protein contents (Siddique et al., 2012; Abdel Latef, 2013; El-Beltagi and Mohamed, 2013; Mondal, 2013), perturb the absorption of nutrients such as $\mathrm{N}$, $\mathrm{P}, \mathrm{K}, \mathrm{Ca}, \mathrm{Mg}, \mathrm{Mn}, \mathrm{Cu}, \mathrm{Zn}, \mathrm{Fe}$, and Ni (Sandalio et al., 2001; Siddique et al., 2012; Abdel Latef, 2013), and can also elevate the reactive oxygen species (ROS) levels (Ahmad et al., 2010, 2015). The excessive or non-metabolized ROS can lead to oxidation of organic molecules like lipids (Ahmad et al., 2010, 2015). The lipid peroxidation is generally reflected by increased concentration of malondialdehyde (MDA) content (Abdel Latef, 2013; Ahmad et al., 2015; Anjum et al., 2015).

Plant can sustain cellular ROS-attack through important endogenous protective strategies consisting of enzymatic and non-enzymatic systems (Ahmad et al., 2008, 2010, 2015, 2016a,b; Hasanuzzaman and Fujita, 2011, 2013). Antioxidant defense enzymes like superoxide dismutase (SOD), catalase (CAT), ascorbate peroxidase (APX), and glutathione reductase (GR) have been reported to reduce the concentrations of superoxide $\left(\mathrm{O}_{2}^{\bullet-}\right)$ and hydrogen peroxide $\left(\mathrm{H}_{2} \mathrm{O}_{2}\right)$ content in plants (Ahmad et al., 2015). Accumulation of protective solutes like Pro and protein in the leaf is a unique plant response to heavy metal stress (El-Beltagi and Mohamed, 2013). Total phenols and flavonoids got induced under low concentrations of metal stress in plants; however, their levels can decline at higher metal concentrations (Cetin et al., 2014). During the last decade, efforts were made to control the level and improve the efficiency of above mentioned defense system components by exogenously supplying mineral elements (Anjum et al., 2012; Nazar et al., 2012) and phytohormones (Khan et al., 2012; Asgher et al., 2015) to the stressed plants.

Calcium $(\mathrm{Ca})$ is a divalent cation and an essential element that plays important role in the structure and permeability of cell membranes, plant cell division and elongation, carbohydrate translocation and N-metabolism (White, 2000; El-Beltagi and Mohamed, 2013). Ca also plays regulatory role in plant cell metabolism, signal transduction and in the absorption of nutrients across cell membranes (Talukdar, 2012; El-Beltagi and Mohamed, 2013). Recent studies showed a major role of $\mathrm{Ca}$ in alleviating the inhibitory effects of $\mathrm{Cd}$ on growth and physiological processes of plants (Suzuki, 2005; Siddique et al., 2012; El-Beltagi and Mohamed, 2013; Ahmad et al., 2015). Potassium $(\mathrm{K})$ is also an essential macronutrient and the most abundant cation in plant tissues. It consists of up to $10 \%$ on the basis of dry weight (Zhao et al., 2003; Siddique et al., 2012). K plays multifarious roles in plant growth and development as it stimulates cell elongation and preserves osmoregulation, and is also involved in stomatal movement, photosynthesis, decrease uptake of Cd, synthesis of soluble carbohydrates, protein, and soluble nitrogen containing compounds (Zhao et al., 2003; Siddique et al., 2012; Zorb et al., 2014). It also acts as a cofactor for many enzymes and activates several enzymes by changing their conformation through the stabilization of $\mathrm{pH}$ between 7.0 and 8.0 (Mengel, 2007; Siddique et al., 2012).

Legumes are more sensitive to $\mathrm{Cd}$ toxicity than cereals and grasses and thus they can lead to severe suppression of biomass and yield production even under minute quantities of Cd (Shamsi et al., 2008). Chickpea (Cicer arietinum L.) is an essential legume crop grown worldwide because it serves as a prime source of proteins for the growing population and it is also used as green manure and fodder for animals. Apart from the proteins, the seeds are also rich in fats and carbohydrates (Rasool et al., 2013, 2015). Insights into C. arietinum responses to Cd-exposure, and potential strategies for minimization of Cd-impacts are meager in literature. Additionally, the efficacy of $\mathrm{Ca}$ and $\mathrm{K}$ in alleviating $\mathrm{Cd}$ stress has not been tested in legumes such as $C$. arietinum. So, this work was undertaken to check whether exogenous application of $\mathrm{Ca}$ and $\mathrm{K}$ can protect $C$. arietinum health and 
productivity against Cd exposure. Notably, important physiobiochemical parameters, enzymatic activities and the status of organic osmolyte (Pro) and secondary metabolites were assessed to understand potential mechanisms underlying of Cd-tolerance in C. arietinum.

\section{MATERIALS AND METHODS}

\section{Plant Culture and Exposure Conditions}

Seeds of chickpea (Cicer arietinum L.) were sown in pots containing peat, perlite and sand (1:1:1, v/v/v) under glasshouse conditions. Four-days old germinated $C$. arietinum seedlings were shifted to pots (one plant per pot) supplemented with nutrient solution $\left(200 \mathrm{ml} \mathrm{pot}^{-1}\right)$. Seedlings were allowed to grow for one more week at average day/night temperature of $24^{\circ} \mathrm{C} / 15^{\circ} \mathrm{C}$. The 11 -day-old-plants were treated with different concentrations of $\mathrm{Cd}\left(\mathrm{CdSO}_{4} .8 \mathrm{H}_{2} \mathrm{O}\right)$ dissolved in nutrient solution with or without spray of $\mathrm{Ca}\left(\mathrm{CaCl}_{2}\right)$ and $\mathrm{K}\left(\mathrm{KCl}_{2}\right)$. Treatments consisted of: C- Nutrient solution alone (control); $\mathrm{C}+\mathrm{Ca}: 0 \mu \mathrm{M} \mathrm{Cd}+50 \mathrm{mM} \mathrm{Ca}+0 \mathrm{mM} \mathrm{K}$; C $+\mathrm{K}: 0 \mu \mathrm{M} \mathrm{Cd}$ $+0 \mathrm{mM} \mathrm{Ca}+10 \mathrm{mM} \mathrm{K} ; \mathrm{C}+\mathrm{Ca}+\mathrm{K}: 0 \mu \mathrm{M} \mathrm{Cd}+50 \mathrm{mM} \mathrm{Ca}+$ $10 \mathrm{mM} \mathrm{K}$; Cd stress alone: $200 \mu \mathrm{M} \mathrm{Cd}+0 \mathrm{mM} \mathrm{Ca}+0 \mathrm{mM} \mathrm{K}$; $\mathrm{Cd}+\mathrm{Ca}: 200 \mu \mathrm{M}$ Cd $+50 \mathrm{mM} \mathrm{Ca}+0 \mathrm{mM} \mathrm{K}$; Cd + K: $200 \mu \mathrm{M}$ $\mathrm{Cd}+0 \mathrm{mM} \mathrm{Ca}+10 \mathrm{mM} \mathrm{K} ; \mathrm{Cd}+\mathrm{Ca}+\mathrm{K}: 200 \mu \mathrm{M} \mathrm{Cd}+50 \mathrm{mM}$ $\mathrm{Ca}+10 \mathrm{mM} \mathrm{K}$.

Cd was applied to pots every week from the first day of treatment (i.e., 11-day-old plants) up to day 30 (41-day-old plants) excluding the control which was supplied with nutrient solution only. $\mathrm{CaCl}_{2}(50 \mathrm{mM})$ and $\mathrm{KCl}_{2}(10 \mathrm{mM})$ were mixed with Tween-20, and sprayed to plants with a manual sprayer $\left(10 \mathrm{ml} \mathrm{plant}^{-1}\right)$ every alternate day, from the 7 th day of the treatment-initiation. The $\mathrm{Ca}$ and $\mathrm{K}$ concentrations were selected based on our preliminary experiments. Each treatment was replicated five times in a randomized block design and each replicate included 5 plants.

\section{Estimations and Bioassays Growth and Crop Yield}

At the end of the experiment the plants were taken out of the pots and washed well with tap water. Shoot and root length was measured with a scale. Fresh weight (FW) of shoot and root was measured directly by weighing the fresh samples. For the dry weight (DW), the samples were oven dried for $24 \mathrm{~h}$ at $80^{\circ} \mathrm{C}$ and then weighed. Yield parameters (pods and seeds) were also measured manually.

\section{Cadmium Accumulation}

The Cd accumulation in the shoot and root tissues was determined using a Perkin-Elmer (Analyst Model 300) atomic absorption spectrophotometer. The heavy metal content was expressed as $\mu \mathrm{gg}^{-1}$.

\section{Photosynthetic Pigments}

The photosynthetic pigments were determined by the method of Hiscox and Israelstam (1979). The absorbances were read at 480, 510, 645, $663 \mathrm{~nm}$ by spectrophotometer (Beckman 640 D, USA) with DMSO as blank.

\section{Proline and Protein}

The Pro content in leaves was estimated by the method of Bates et al. (1973). The absorbance was measured spectrophotometerically (Beckman $640 \mathrm{D}$, USA) at $520 \mathrm{~nm}$ and toluene was used as blank.

The method of Bradford (1976) was employed for the estimation of protein from leaves. The absorbance was measured at $595 \mathrm{~nm}$ by spectrophotometer (Beckman $640 \mathrm{D}$, USA) with bovine serum albumin as blank.

\section{Total Phenols and Flavonoids}

The leaf sample was grounded and extracted with methanol at room temperature. The extract containing phenolic content was reduced by Folin-Ciocalteu reagent using the method of Chun et al. (2003). The mg gallic acid equivalent (GAE) $\mathrm{g}^{-1}$ of extract ( $\mathrm{mg} \mathrm{g}^{-1}$ ) expresses the total phenolic content. The flavonoids content was estimated as per colorimetric method described by Zhishen et al. (1999). Catechin was used as standard for the calibration curve. The absorbance was read at $510 \mathrm{~nm}$ by spectrophotometer (Beckman $640 \mathrm{D}$, USA) and flavonoids content was expressed as $\mathrm{mg}$ catechin equivalents $\mathrm{g}^{-1}$ of extract $\left(\mathrm{mg} \mathrm{g}^{-1}\right)$.

\section{$\mathrm{H}_{2} \mathrm{O}_{2}$ and MDA}

$\mathrm{H}_{2} \mathrm{O}_{2}$ in fresh leaves was estimated by the method of Velikova et al. (2000). The absorbance was read at $390 \mathrm{~nm}$ by spectrophotometer (Beckman 640 D, USA). For the estimation of MDA content in fresh leaves, the method of Heath and Packer (1968) was employed. The absorbances were recorded at 532 and $600 \mathrm{~nm}$ spectrophotometerically (Beckman $640 \mathrm{D}$, USA) for the calculation of MDA equivalents. Thiobarbituric acid (1\%) in 20\% trichloroacetic acid was used as control.

\section{Enzyme Extractions and Assays}

Fresh leaves $(0.5 \mathrm{~g} / \mathrm{sample})$ were homogenized in presence of $100 \mathrm{mM}$ Tris- $\mathrm{HCl}$ (5.0 ml, pH 7.5), 5.0 mM DTT (Dithiothreitol), $10 \mathrm{mM} \mathrm{MgCl}_{2}, 1.0 \mathrm{mM}$ EDTA (Ethylenediaminetetraacetic acid), $5.0 \mathrm{mM}$ magnesium acetate and $1.5 \%$ Polyvinylpyrrolidone (PVP)-40. The reaction mixture was supplemented with serine and cysteine proteinase inhibitors $[1.0 \mathrm{mM}$ Phenylmethanesulfonyl fluoride (PMSF) + $1.0 \mu \mathrm{g} / \mathrm{ml}$ aproptinin]. The homogenate was centrifuged at $10,000 \times$ $\mathrm{g}$ for $15 \mathrm{~min}\left(4^{\circ} \mathrm{C}\right)$ after the filtration through cheesecloth. The supernatants collected served as sources for determination of SOD (EC 1.15.1.1), CAT (EC 1.11.1.6), and GR (EC 1.6.4.2) activities. For the determination of APX activity, leaf sample was separately grounded in a homogenizing medium containing $2.0 \mathrm{mM}$ ascorbic acid (AsA).

SOD activity was determined by the method of Van Rossum et al. (1997) after the photoreduction of nitrobluetetrazolium (NBT). The absorbance was recorded spectrophotometerically (Beckman $640 \mathrm{D}, \mathrm{USA}$ ) at $560 \mathrm{~nm}$. One unit of SOD is the quantity of protein that hampers $50 \%$ photoreduction of NBT and the activity was expressed as enzyme unit (EU) $\mathrm{mg}^{-1}$ protein.

The method of Luck (1974) was employed for the assay of CAT activity. The absorbance was recorded at $240 \mathrm{~nm}$ by 
spectrophotometer (Beckman $640 \mathrm{D}$, USA) and $\mathrm{EU} \mathrm{mg}^{-1}$ protein expresses the CAT activity. The method of Nakano and Asada (1981) was used for the assay of APX activity (EC 1.11.1.11). The absorbance was measured spectrophotometerically (Beckman $640 \mathrm{D}$, USA) at $290 \mathrm{~nm}$ and $\mathrm{EU} \mathrm{mg} \mathrm{mg}^{-1}$ protein expresses the APX activity. One unit of APX is the quantity of protein used to break down $1.0 \mu \mathrm{mol}$ of substrate per min at $25^{\circ} \mathrm{C}$.

The activity of other important enzyme GR was estimated by the method of Carlberg and Mannervik (1985). The absorbance was read at $340 \mathrm{~nm}$ by spectrophotometer (Beckman $640 \mathrm{D}$, USA). GR activity was expressed as $\mu$ mol NADPH oxidized $\mathrm{min}^{-1}$ (EU mg ${ }^{-1}$ protein).

\section{Nutritional Elements}

Dried shoot and root samples $(0.1 \mathrm{~g})$ were powdered and digested in $\mathrm{H}_{2} \mathrm{SO}_{4} / \mathrm{HNO}_{3}$ mixture $(1 / 5, \mathrm{v} / \mathrm{v})$ for $24 \mathrm{~h}$, then were treated with $\mathrm{HNO}_{3} / \mathrm{HClO}_{4}$ mixture $(5 / 1, \mathrm{v} / \mathrm{v})$. Atomic absorption spectrophotometer (Analyst 300, Perkin-Elmer, Germany) was used for the estimation of elemental content ( $\mathrm{S}, \mathrm{Mn}, \mathrm{Mg}$, Ca, and $\mathrm{K}$ ) in both shoot and root.

\section{Statistical Analysis}

Statistical analysis was executed utilizing one-way analysis of variance (ANOVA) followed by Duncan's Multiple Range Test (DMRT). The values are mean \pm standard error (SE) of five replicates in each group. $P \leq 0.05$ were considered as significant.

\section{RESULTS}

\section{Growth, Biomass Yield, and Yield Attributes}

The length and weight (fresh and dry) of shoot and root and yield attributes in terms of number of pods and seed yield in $C$. arietinum subjected to $\mathrm{Ca}$ and/or $\mathrm{K}$ under $\mathrm{Cd}$ stress and normal conditions are presented in Table 1. Cd stress reduced the shoot length, root length, shoot FW, shoot DW, root FW, root DW, number of pods and seed yield by $58.25,62.50,41.26,21.80$, $48.17,34.84,49.60$, and $52.62 \%$, respectively in comparison with control. Application of $\mathrm{Ca}$ and $\mathrm{K}$ enhanced the shoot length by $66.76,39.05$, and $95.54 \%$ and root length by $34.79,54.09$, and $107.60 \%$ with $\mathrm{Cd}+\mathrm{Ca}, \mathrm{Cd}+\mathrm{K}$ and $\mathrm{Cd}+\mathrm{Ca}+\mathrm{K}$, respectively compared to $\mathrm{Cd}$ treated plants alone (Table 1). The shoot FW and DW were also elevated by the supplementation of $\mathrm{Ca}$ and $\mathrm{K}$ and the maximum increase in shoot FW and DW was 30.59 and $20.60 \%$, respectively with $\mathrm{Cd}+\mathrm{Ca}+\mathrm{K}$ treatment compared to plants treated with $\mathrm{Cd}$ alone (Table 1). The root FW and DW also increased with addition of $\mathrm{Ca}$ and $\mathrm{K}$ and the highest increase in root FW (30.98\%) and root DW (24.41\%) was observed at $\mathrm{Cd}+\mathrm{Ca}+\mathrm{K}$ treatment over the plants treated with $\mathrm{Cd}$ alone (Table 1). The supplementation of $\mathrm{Ca}$ and $\mathrm{K}$ improved the pods by $29.42,25.05$, and $68.51 \%$ with $\mathrm{Cd}+\mathrm{Ca}, \mathrm{Cd}+\mathrm{K}$ and $\mathrm{Cd}+\mathrm{Ca}+\mathrm{K}$ treatments, respectively relative to plants treated with $\mathrm{Cd}$ alone. The seed yield also increased by $52.45 \%$ with $\mathrm{Cd}$ $+\mathrm{Ca}, 47.13 \%$ with $\mathrm{Cd}+\mathrm{K}$ and $92.21 \%$ with $\mathrm{Cd}+\mathrm{Ca}+\mathrm{K}$ treatments over the $\mathrm{Cd}$ treated plants alone (Table 1). Control plants treated with $\mathrm{Ca}$ and $\mathrm{K}$ showed significant elevation in above parameters compared to control plants alone and the more effective treatment was the combination of $\mathrm{Ca}+\mathrm{K}$ compared to their individual effect (Table 1).

\section{Cadmium Accumulation}

The accumulation of Cd was about 2.40-fold in root as compared to shoot. Cd stressed plants treated with $\mathrm{Ca}$ and $\mathrm{K}$ recorded the suppression of $\mathrm{Cd}$ accumulation by $69.04,61.72$, and $78.29 \%$ with $\mathrm{Cd}+\mathrm{Ca}, \mathrm{Cd}+\mathrm{K}$ and $\mathrm{Cd}+\mathrm{Ca}+\mathrm{K}$, respectively in shoot compared to shoot in $\mathrm{Cd}$ treated plants alone. The root $\mathrm{Cd}$ accumulation was also reduced by $82.39 \%$ with $\mathrm{Cd}+\mathrm{Ca}, 69.76 \%$ with $\mathrm{Cd}+\mathrm{K}$ and $85.87 \%$ with $\mathrm{Cd}+\mathrm{Ca}+\mathrm{K}$ treatments relative to plants treated with $\mathrm{Cd}$ alone (Table 2).

\section{Photosynthetic Pigment Content}

Chl $a$, Chl $b$ and total Chl decreased by $48.02,46.51$, and $47.69 \%$, respectively in $\mathrm{Cd}$ treated plants relative to control (Table 3 ). On the other hand, Cd stress significantly increased carotenoids content by $35.89 \%$ over the control. However, application of Ca or $\mathrm{K}$ alone as well as in combination improved photosynthetic pigments in Cd stressed plants. An increase by 44.30, 69.56, 50.00, and $45.28 \%$ in Chl $a, \mathrm{Chl} b$, total Chl and carotenoids, respectively was observed with treatment $\mathrm{Cd}+\mathrm{Ca}+\mathrm{K}$ compared to the plants treated with $\mathrm{Cd}$ alone. Control plants supplemented with $\mathrm{Ca}$ and $\mathrm{K}$ alone as well as in combination also showed increase in pigment content (Table 3).

\section{Proline and Protein Contents}

The results related to the effect of $\mathrm{Ca}$ and $\mathrm{K}$ on Pro and protein content in $\mathrm{Cd}$ stressed chickpea plants are presented in Table 3. The Pro and protein contents increased by 5- and 2 -fold, respectively in Cd stressed plants relative to control. Supplementation of $\mathrm{Ca}$ and $\mathrm{K}$ showed further accumulation in Pro and protein content and the maximum increase in Pro (30.99\%) and protein $(53.57 \%)$ was recorded in plants treated with $\mathrm{Cd}+\mathrm{Ca}+\mathrm{K}$ treatment over the plants treated with $\mathrm{Cd}$ alone. Application of $\mathrm{Ca}$ and $\mathrm{K}$ in combination was more effective in control as well as in treated plants (Table 3).

\section{Total Phenols and Flavonoids}

The total phenols and flavonoids contents were declined by 37.93 and $45.21 \%$ in Cd stressed plants comparison to control plants (Table 3). However, supplementation of $\mathrm{Ca}$ and $\mathrm{K}$ increased the total phenols by $24.91,20.93$, and $30.23 \%$ with $\mathrm{Cd}+\mathrm{Ca}, \mathrm{Cd}$ $+\mathrm{K}$ and $\mathrm{Cd}+\mathrm{Ca}+\mathrm{K}$ treatments, respectively as compared to plants treated with $\mathrm{Cd}$ alone. Insignificant increase in total phenols was observed by the application of $\mathrm{Ca}$ and $\mathrm{K}$ individually as well as in combination to control plants (Table 3). Flavonoids content also enhanced by $19.66 \%$ with $\mathrm{Cd}+\mathrm{Ca}, 18.20 \%$ with $\mathrm{Cd}$ $+\mathrm{K}$ and $26.94 \%$ with $\mathrm{Cd}+\mathrm{Ca}+\mathrm{K}$ treatments relative to $\mathrm{Cd}$ treated plants alone (Table 3 ). $\mathrm{Ca}$ and $\mathrm{K}$ in combination were proved to me more beneficial as compared to their individual effect in both control and Cd treated plants. Significant increase in flavonoids content was observed in plants supplied with $\mathrm{Ca}$ and $\mathrm{K}$ individually as well as in combination (Table 3). 
TABLE 1 | Effect of calcium (Ca) and potassium (K) alone and in combination on shoot and root length (cm plant ${ }^{-1}$ ), shoot FW and DW (g plant ${ }^{-1}$ ), root FW and DW (g plant ${ }^{-1}$ ), number of pods (pod plant ${ }^{-1}$ ) and seed yield (g plant ${ }^{-1}$ ) in chickpea (Cicer arietinum L.) plants under normal and cadmium (Cd) stress conditions.

\begin{tabular}{|c|c|c|c|c|c|c|c|c|}
\hline Growth traits & \multicolumn{8}{|c|}{ Treatments } \\
\hline Shoot length & $24.72 \pm 1.37 b$ & $29.15 \pm 1.45 a$ & $27.44 \pm 1.41 a$ & $32.27 \pm 1.48 \mathrm{a}$ & $10.32 \pm 1.10 \mathrm{e}$ & $17.21 \pm 1.24 \mathrm{c}$ & $14.35 \pm 1.18 d$ & $20.18 \pm 1.26 \mathrm{c}$ \\
\hline Root length & $9.12 \pm 1.01 \mathrm{c}$ & $11.15 \pm 1.13 b$ & $12.33 \pm 1.15 b$ & $16.28 \pm 1.20 a$ & $3.42 \pm 0.39 g$ & $4.61 \pm 0.48 f$ & $5.27 \pm 0.53 e$ & $7.10 \pm 0.68 d$ \\
\hline Shoot FW & $6.01 \pm 0.68 c$ & $6.21 \pm 0.75 b$ & $6.15 \pm 0.72 b$ & $6.81 \pm 0.81 a$ & $3.53 \pm 0.41 \mathrm{~g}$ & $3.91 \pm 0.46 f$ & $4.10 \pm 0.51 \mathrm{e}$ & $4.61 \pm 0.57 d$ \\
\hline Shoot DW & $2.11 \pm 0.33 b$ & $2.25 \pm 0.36 b$ & $2.29 \pm 0.39 b$ & $2.62 \pm 0.43 a$ & $1.65 \pm 0.13 \mathrm{e}$ & $1.72 \pm 0.17 d$ & $1.78 \pm 0.18 d$ & $1.99 \pm 0.23 c$ \\
\hline Number of pods & $25.02 \pm 1.43 c$ & $28.35 \pm 1.47 b$ & $28.11 \pm 1.45 b$ & $32.62 \pm 1.58 a$ & $12.61 \pm 1.04 f$ & $16.32 \pm 1.15 \mathrm{e}$ & $15.77 \pm 1.14 \mathrm{e}$ & $21.25 \pm 1.38 d$ \\
\hline Seed yield & $5.15 \pm 0.54 c$ & $5.94 \pm 0.62 b$ & $5.91 \pm 0.60 b$ & $6.11 \pm 0.66 a$ & $2.44 \pm 0.23 g$ & $3.72 \pm 0.41 f$ & $3.59 \pm 0.32 e$ & $4.69 \pm 0.44 d$ \\
\hline
\end{tabular}

Data presented are the means \pm standard error (SE) of five independent replications $(n=5)$. Different letters indicate significant difference $(P \leq 0.05)$ among the treatments. FW, fresh weight; DW, dry weight.

TABLE 2 | Effect of calcium (Ca) and potassium (K) alone and in combination on cadmium (Cd) content in shoot and root ( $\mu \mathrm{mol} \mathrm{g}^{-1} \mathrm{DW}$ ) in chickpea (Cicer arietinum L.) seedlings under normal and cadmium (Cd) stress conditions.

Traits Treatments

\begin{tabular}{|c|c|c|c|c|c|c|c|c|}
\hline & C & $\mathrm{C}+\mathrm{Ca}$ & $C+K$ & $\mathrm{C}+\mathrm{Ca}+\mathrm{K}$ & Cd & $\mathrm{Cd}+\mathrm{Ca}$ & $C d+K$ & $\mathrm{Cd}+\mathrm{Ca}+\mathrm{K}$ \\
\hline Root Cd & ND & ND & ND & ND & $37.31 \pm 1.82 a$ & $6.57 \pm 0.80 c$ & $11.28 \pm 1.02 b$ & $5.27 \pm 0.58 d$ \\
\hline
\end{tabular}

Data presented are the means \pm standard error (SE) of five independent replications $(n=5)$. Different letters indicate significant difference $(P \leq 0.05)$ among the treatments. DW, dry weight; ND, not detected.

TABLE 3 | Effect of calcium (Ca) and potassium (K) alone and in combination on the contents of chlorophyll (Chl) ( $\left.\mathrm{mg} \mathrm{g}^{-1} \mathrm{FW}\right), \mathrm{proline}^{-}\left(\mu \mathrm{g} \mathrm{g} \mathrm{g}^{-1} \mathrm{FW}\right.$ ), protein ( $\mathrm{mg} \mathrm{g}^{-1} \mathrm{FW}$ ), total phenols (mg gallic acid equivalent (GAE) $\mathrm{g}^{-1}$ extract) and flavonoids content ( $\mathrm{mg}$ Catechin $\mathrm{g}^{-1}$ extract) in chickpea (Cicer arietinum L.) leaves under normal and cadmium (Cd) stress conditions.

\begin{tabular}{lcrrrrrrr}
\hline \multirow{2}{*}{ Traits } & \multicolumn{9}{c}{ Treatments } \\
\cline { 2 - 9 } & $\mathbf{C}$ & $\mathbf{C}+\mathbf{C a}$ & $\mathbf{C}+\mathbf{K}$ & $\mathbf{C}+\mathbf{C a}+\mathbf{K}$ & $\mathbf{C d}$ & $\mathbf{C d}+\mathbf{C a}$ & $\mathbf{C d}+\mathbf{K}$ & $\mathbf{C d}+\mathbf{C a}+\mathbf{K}$ \\
\hline Chl $a$ & $1.52 \pm 0.65 \mathrm{c}$ & $1.75 \pm 0.72 \mathrm{~b}$ & $1.63 \pm 0.69 \mathrm{~b}$ & $1.94 \pm 0.77 \mathrm{a}$ & $0.79 \pm 0.09 \mathrm{~g}$ & $0.96 \pm 0.15 \mathrm{e}$ & $0.87 \pm 0.10 \mathrm{f}$ & $1.14 \pm 0.23 \mathrm{~d}$ \\
Chl $b$ & $0.43 \pm 0.06 \mathrm{c}$ & $0.51 \pm 0.07 \mathrm{~b}$ & $0.48 \pm 0.07 \mathrm{~b}$ & $0.79 \pm 0.12 \mathrm{a}$ & $0.23 \pm 0.02 \mathrm{e}$ & $0.31 \pm 0.03 \mathrm{~d}$ & $0.29 \pm 0.03 \mathrm{~d}$ & $0.39 \pm 0.05 \mathrm{~d}$ \\
Total Chl & $1.95 \pm 0.75 \mathrm{~d}$ & $2.26 \pm 0.88 \mathrm{~b}$ & $2.11 \pm 0.81 \mathrm{c}$ & $2.73 \pm 0.99 \mathrm{a}$ & $1.02 \pm 0.17 \mathrm{~h}$ & $1.27 \pm 0.28 \mathrm{f}$ & $1.16 \pm 0.25 \mathrm{~g}$ & $1.53 \pm 0.66 \mathrm{e}$ \\
Carotenoids & $0.39 \pm 0.01 \mathrm{e}$ & $0.45 \pm 0.04 \mathrm{~d}$ & $0.41 \pm 0.04 \mathrm{~d}$ & $0.49 \pm 0.05 \mathrm{~d}$ & $0.53 \pm 0.12 \mathrm{c}$ & $0.69 \pm 0.19 \mathrm{~b}$ & $0.57 \pm 0.16 \mathrm{~b}$ & $0.77 \pm 0.21 \mathrm{a}$ \\
Proline & $27.10 \pm 1.31 \mathrm{~g}$ & $32.71 \pm 1.52 f$ & $30.11 \pm 1.48 \mathrm{f}$ & $38.32 \pm 1.66 \mathrm{e}$ & $135.96 \pm 3.21 \mathrm{~d}$ & $150.96 \pm 3.96 \mathrm{~b}$ & $146.32 \pm 3.75 \mathrm{c}$ & $178.10 \pm 3.42 \mathrm{a}$ \\
Protein & $18.31 \pm 1.15 \mathrm{~h}$ & $24.41 \pm 1.35 f$ & $21.70 \pm 1.30 \mathrm{~g}$ & $29.43 \pm 1.44 \mathrm{e}$ & $37.71 \pm 1.65 \mathrm{~d}$ & $48.37 \pm 1.72 \mathrm{~b}$ & $44.53 \pm 1.68 \mathrm{c}$ & $57.91 \pm 1.83 \mathrm{a}$ \\
Total phenols & $4.85 \pm 0.56 \mathrm{ab}$ & $4.93 \pm 0.58 \mathrm{a}$ & $4.92 \pm 0.58 \mathrm{a}$ & $4.99 \pm 0.61 \mathrm{a}$ & $3.01 \pm 0.25 \mathrm{e}$ & $3.76 \pm 0.34 \mathrm{~d}$ & $3.64 \pm 0.31 \mathrm{~d}$ & $3.92 \pm 0.42 \mathrm{c}$ \\
Flavonoids & $7.52 \pm 0.78 \mathrm{c}$ & $7.65 \pm 0.84 \mathrm{~b}$ & $7.77 \pm 0.88 \mathrm{~b}$ & $7.89 \pm 0.97 \mathrm{a}$ & $4.12 \pm 0.48 f$ & $4.93 \pm 0.59 \mathrm{e}$ & $4.87 \pm 0.57 \mathrm{e}$ & $5.23 \pm 0.67 \mathrm{~d}$
\end{tabular}

Data presented are the means \pm standard error $(S E)$ of five independent replications $(n=5)$. Different letters indicate significant difference $(P \leq 0.05)$ among the treatments. FW, fresh weight.

\section{$\mathrm{H}_{2} \mathrm{O}_{2}$ and MDA}

Cd treatment led to a sharp accumulation of $\mathrm{H}_{2} \mathrm{O}_{2}(191.24 \%)$ and MDA (49.05\%) over the control plants. Addition of $\mathrm{Ca}$ and $\mathrm{K}$ to $\mathrm{Cd}$ treated plants reduced the $\mathrm{H}_{2} \mathrm{O}_{2}$ accumulation by $27.68 \%$ with $\mathrm{Cd}+\mathrm{Ca}, 21.99 \%$ with $\mathrm{Cd}+\mathrm{K}$ and $49.20 \%$ with $\mathrm{Cd}+\mathrm{Ca}+\mathrm{K}$ treatments compared to plants treated with $\mathrm{Cd}$ alone. The MDA content also decreased by $16.56,8.06$, and $27.39 \%$ with $\mathrm{Cd}+\mathrm{Ca}$, $\mathrm{Cd}+\mathrm{K}$ and $\mathrm{Cd}+\mathrm{Ca}+\mathrm{K}$, respectively relative to $\mathrm{Cd}$ treated plants alone (Figures 1A,B).

\section{Activities of Antioxidant Enzymes}

$\mathrm{Cd}$ stress boosted the SOD, CAT, APX, and GR activity by $67.99,83.90,183.67$, and $215.81 \%$, respectively as compared to control plants. $\mathrm{Cd}$ treated plants supplemented with $\mathrm{Ca}$ and $\mathrm{K}$ further enhanced the activities of SOD by $21.08 \%$, CAT by $14.03 \%$, APX by $70.43 \%$ and GR by $53.52 \%$ with $\mathrm{Cd}+\mathrm{Ca}+\mathrm{K}$ treatments over the plants treated with $\mathrm{Cd}$ alone (Figures 2A-D). Control plants supplemented with $\mathrm{Ca}$ and $\mathrm{K}$ individually as well as in combination 


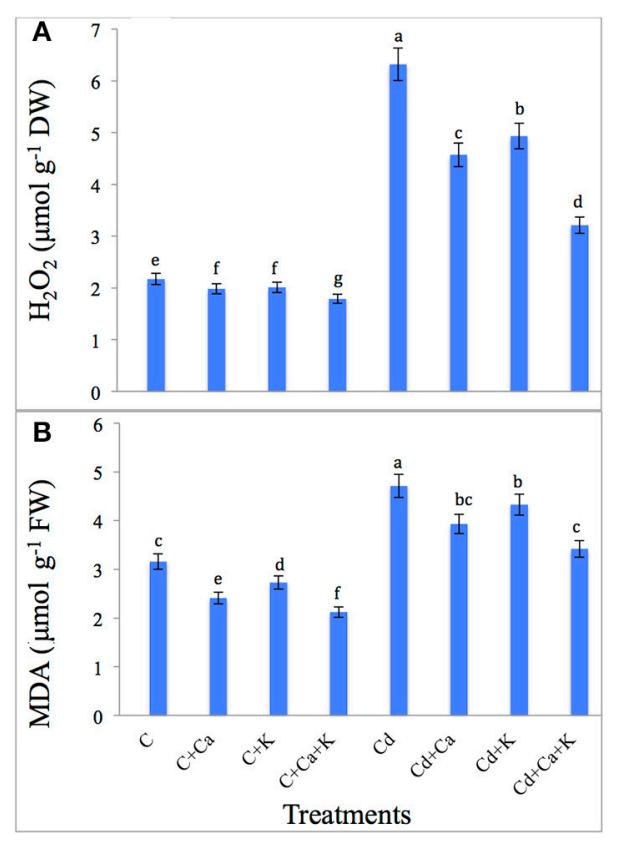

FIGURE 1 | Effect of calcium (Ca) and potassium (K) alone and in combination on $\mathrm{H}_{2} \mathrm{O}_{2}(A)$, and lipid peroxidation (MDA) (B) in chickpea seedlings under cadmium (Cd) stress. Data presented are the means \pm SE $(n=5)$. Different letters indicate significant difference $(P \leq 0.05)$ among the treatments.

also boosted antioxidant activity in untreated plants (Figures 2A-D).

\section{Mineral Elements}

Cd stress significantly affected the pools of mineral nutrients in C. arietinum shoot and root. $\mathrm{S}, \mathrm{Mn}, \mathrm{Mg}, \mathrm{Ca}$ and $\mathrm{K}$ contents in shoot were declined by $36.74,64.04,47.14,33.84$, and $49.20 \%$, respectively with $\mathrm{Cd}$ treatment under the control plants. The root mineral elements also showed decline by 48.21, 16.52, 18.36, 14.15 , and $37.22 \%$ in S, Mn, Mg, Ca, and $\mathrm{K}$, respectively with Cd treatment relative to control plants. The application of $\mathrm{Ca}$ and $\mathrm{K}$ individually as well as in combination improved the mineral elements in both shoot and root under Cd toxicity. The combined effect of $\mathrm{Ca}+\mathrm{K}$ proved to be more beneficial in comparison to individual effects of $\mathrm{Ca}$ and $\mathrm{K}$ in restoring the mineral nutrients in shoot and root in control as well as in $\mathrm{Cd}$ treated plants (Table 4).

\section{DISCUSSION}

$\mathrm{Cd}$ is a non-essential element and its accumulation hampers the growth and development of the plant (Abdel Latef, 2013; Ahmad et al., 2015; Asgher et al., 2015). The suppression in growth under Cd toxicity may be attributed to restricted water and nutritional uptake by plant roots (Dinakar et al., 2009), disturbance in photosynthesis (Dong et al., 2005), reduction of cell wall components and changes in carbohydrates metabolism (Abdel Latef, 2013; Hussain et al., 2013). Our results are in

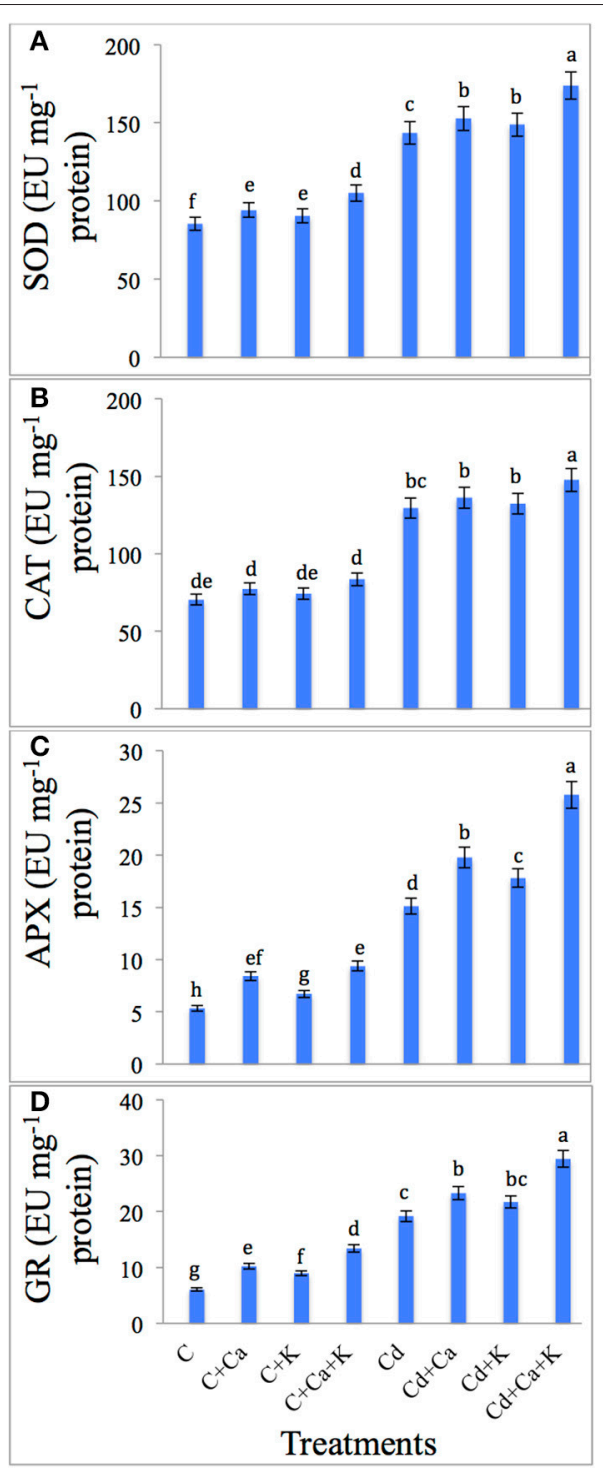

FIGURE 2 | Effect of calcium (Ca) and potassium (K) alone and in combination on the activity of superoxide dismutase (SOD) (A), catalase (CAT) (B), ascorbate peroxidase (APX) (C), and glutathione reductase (GR) (D) in chickpea seedlings under cadmium (Cd) stress. Data presented are the means $\pm \operatorname{SE}(n=5)$. Different letters indicate significant difference $(P \leq 0.05)$ among the treatments.

harmony with Mondal (2013) who reported that the reduction of root growth may be due to direct interference of $\mathrm{Cd}$ with some hydrolytic enzymes, which plays a pivotal role in transporting the food to the primary root and shoot. He also reported that the reduction in the shoot length may be due to the direct inhibition of cell elongation or cell division, retarded root growth and low nutrients/water transport to the upper parts of shoot (Mondal, 2013). Foliar application of $\mathrm{Ca}$ and $\mathrm{K}$ alone as well as in combination mitigated the negative impact of Cd toxicity and enhanced the plant growth and yield attributes of chickpea plants (Figure 3), indicating the direct or indirect role of both elements in improving plant growth and biomass yield even 
TABLE 4 | Effect of calcium (Ca) and potassium (K) alone and in combination on mineral elements content in shoot and root ( $\mu \mathrm{g} \mathrm{g} \mathrm{g}^{-1} \mathrm{DW}$ ) of chickpea (Cicer arietinum L.) plants under normal and cadmium (Cd) stress conditions.

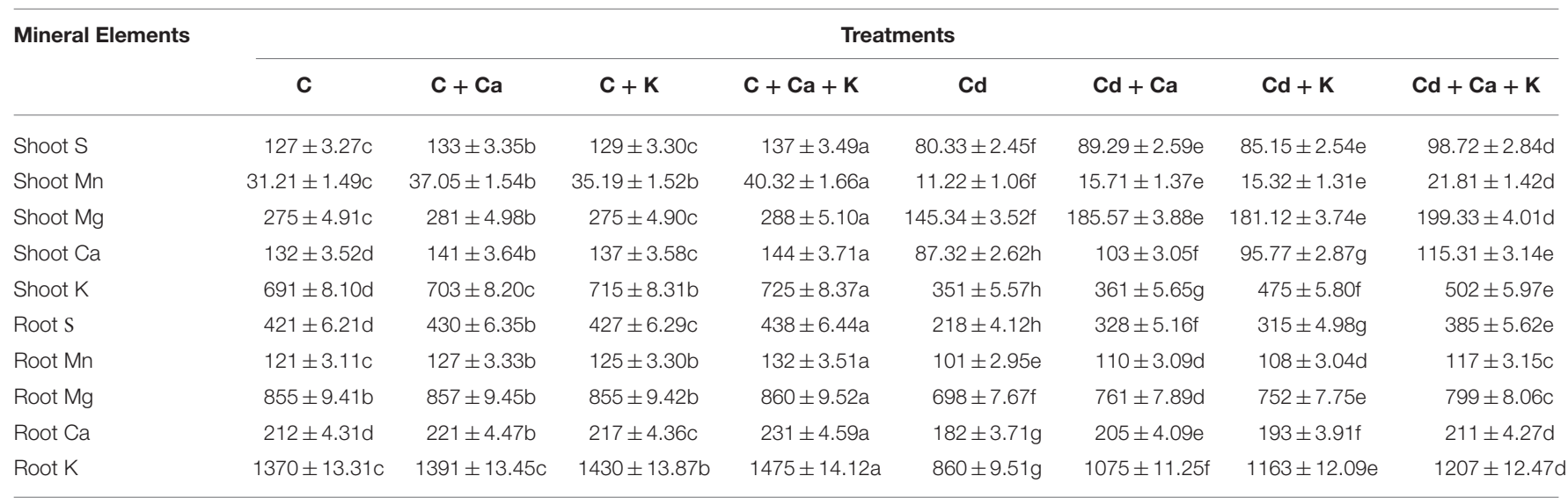

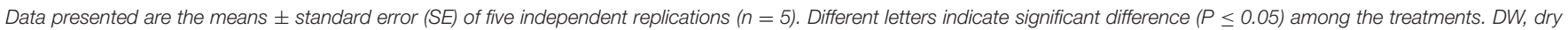
weight.

under heavy metal stress. Ca may favor cell elongation and cell expansion, finally enhancing the plant growth and was also reported by Hernandez and Almansa (2002) in pea and Abdel Latef (2011a) in canola. This finding is in consistence with Ismail (2008) who reported that supplementation of Ca mitigated the growth inhibition induced by $\mathrm{Cd}$ toxicity in common bean. Our previous work on mustard also confirmed that $\mathrm{Ca}$ alleviated the $\mathrm{Cd}$ induced suppression in growth and biomass yield (Ahmad et al., 2015). Eller and Brix (2016) also proved that shoot and root biomass was enhanced by addition of Ca to Cd stressed Brassica juncea plants. K plays a vital role in nullifying the harmful effects of stress on plants as it serves as a catalyst for various enzymatic processes that are essential for plant growth and development (Cakmak, 2005). Deficiency of $\mathrm{K}$ in plants has been reported to decrease the rate of net photosynthesis and ribulose-1, 5bisphosphate carboxylase activity (Cakmak, 2005; Weng et al., 2007). Song et al. (2015) have reported that application of $\mathrm{K}$ restricted the fresh weight of peach (Prunus persica) seedlings under $\mathrm{Zn}$-toxicity. According to the present study $\mathrm{Ca}$ and $\mathrm{K}$ in combination proved to be more effective than individual $\mathrm{Ca}$ and $\mathrm{K}$ and the results are in conformity with the finding of Siddique et al. (2012) in Vicia faba under Cd toxicity.

$\mathrm{Cd}$ decreased the number of pods and seed yield which coincides with the findings of Siddhu and Khan (2012) in Phaseolus mungo. Fatoba et al. (2012) also reported the decrease in yield parameters with increasing concentration of $\mathrm{Cd}$ in Arachis hypogaea and Glycine max. The negative effects of $\mathrm{Cd}$ stress on yield attributes have also been reported by Kumar and Dhingra (2005) in mungbean and Ali Khan and Siddhu (2006) in Vigna mungo. Application of $\mathrm{Ca}$ and $\mathrm{K}$ enhanced the yield parameters under Cd stress in the current study that may be attributed to (i) increased mineral and water uptake, (ii) restoration of photosynthetic pigments and rehabilitation of other metabolic processes affected by $\mathrm{Cd}$ stress.

The accumulation of $\mathrm{Cd}$ was more in root compared to shoot and the results coincided with previous reports on different plant species (Amirjani, 2012; Mondal, 2013). The root is first entry point for immobilization of $\mathrm{Cd}$ by means of the cell wall and extracellular carbohydrates (Amirjani, 2012). The lower accumulation of $\mathrm{Cd}$ in shoot may be due to the retention of $\mathrm{Cd}$ ions in the root and preventing the transport of excess $\mathrm{Cd}$ to the aerial parts of $C$. arietinum. The application of $\mathrm{Ca}$ and $\mathrm{K}$ individually or in combination reduced accumulation of $\mathrm{Cd}$ in both root and shoot in the present study (Figure 3). The protection provided by $\mathrm{Ca}$ for alleviating $\mathrm{Cd}$ toxicity can be due to various mechanisms like (i) the displacement of cellsurface toxic cations by $\mathrm{Ca}$ reduced the negativity of plasma membrane and mitigation the deleterious effect of cationic toxicants (Kinraide, 1998) (ii) elimination of anxious Cd by the formation and exudation of $\mathrm{Cd} / \mathrm{Ca}$ containing crystals from the trichome head cells (Choi et al., 2001) (iii) Cd uptake via $\mathrm{Ca}$ channels blockers, diltiazem, verapmil, nifedipine and nitrendipine (Hinkle et al., 1987) (iv) competition for metal ion influx (Suzuki, 2005), and (v) complexing Cd with phytochelatins such as metalothionin and cysteine-rich proteins (Suzuki et al., 2002; Song et al., 2004). The impact of $\mathrm{K}$ fertilizers on plant accumulation of $\mathrm{Cd}$ has rarely been studied in detail earlier. Availability of $\mathrm{K}$ minimizes the uptake of $\mathrm{Cd}$ as both ions ( $\mathrm{Cd}$ and $\mathrm{K}$ ) are in competition for the same transmembrane carrier (Clarkson and Luttge, 1989; Rivetta et al., 1997). Noraho and Gaur (1995) also reported that $\mathrm{K}$ application resulted in less Cd uptake in Lemna polyrrhiza. The molecular mechanism how $\mathrm{K}$ decreases uptake of Cd needs further elucidation.

Our data regarding the photosynthetic pigments ( $\mathrm{Chl} a, b$, and total $\mathrm{Chl}$ ) in C. arietinum showed decline with $\mathrm{Cd}$ stress. This decline may be due to (i) inhibition of photosynthetic electron transport chain (Siddique et al., 2012), (ii) inhibition of the sulfhydryl requiring enzymes of Chl biosynthesis (Siddique et al., 2012), (iii) damage of PS II reaction center in the leaf (Mondal, 2013), (iv) replacement the central $\mathrm{Mg}^{2+}$ of $\mathrm{Chl}$ in plants to prevent light harvesting (Abdel Latef, 2013), (v) reduction the uptake of $\mathrm{P}$ which contributes to pigment biosynthesis (Abdel Latef, 2013) (vi) induction of lipid peroxidation, which causes degradation of photosynthetic pigments (Abdel Latef, 2013; 


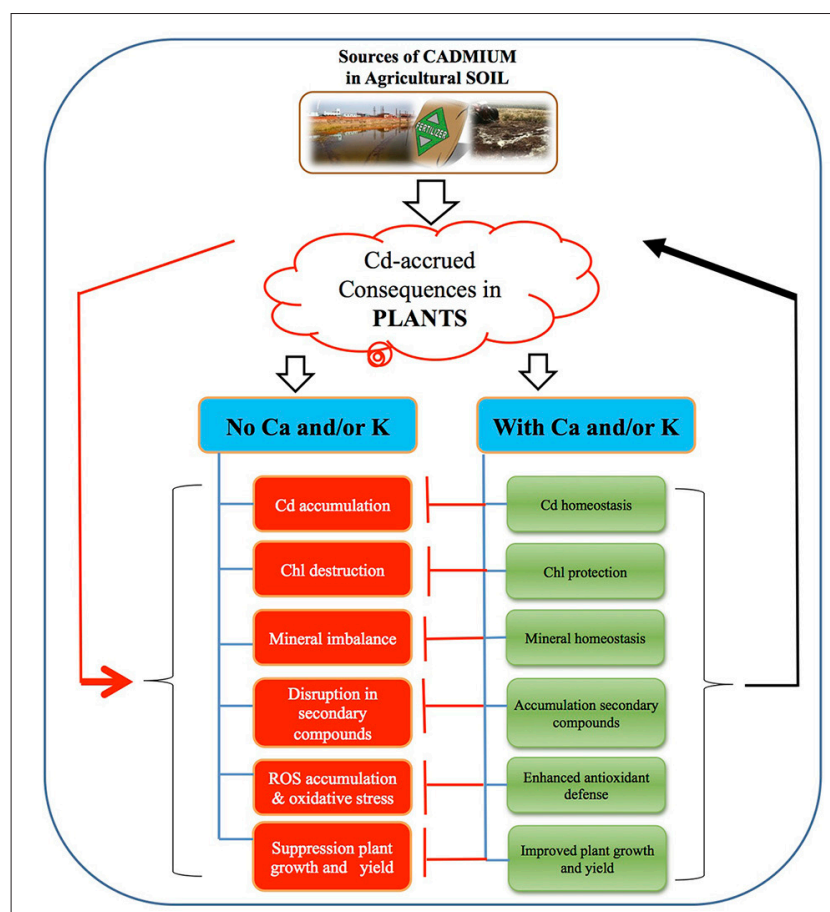

FIGURE 3 | A possible model showing the strategy of calcium (Ca) and/or potassium (K) induced cadmium tolerance in chickpea. Exposure of $C$. arietinum to $C d$ caused an increased in uptake and accumulation of $\mathrm{Cd}$ in plant cells. Elevated cellular-Cd induced chlorophyll (Chl)-destruction, ionic disorder, disruption in secondary metabolites, generation of reactive oxygen species (ROS), leading to suppression of plant growth and yield. On the other side, supplementation of $\mathrm{Ca}$ and or $\mathrm{K}$ resulted into mineral nutrient homeostasis, increased Chl content, accumulation of secondary compounds and higher antioxidant capacity all of which contributed to the mitigation of $\mathrm{Cd}$-induced damage, leading to improved plant growth and yield.

Ahmad et al., 2015). Carotenoids are categorized in lipophilic antioxidant group and have the ability to scavenge various forms of ROS such as singlet oxygen $\left({ }^{1} \mathrm{O}_{2}\right)$ (Mourato et al., 2012). Carotenoids act as precursors to signaling molecules that have a positive impact on plant growth and development and responses under biotic and abiotic stress (El-Beltagi and Mohamed, 2013). Interestingly, in our study, the synthesis of carotenoids decreased the oxidative damage induced by Cd toxicity and is also reported by El-Beltagi and Mohamed (2013) in Pisum sativum and Abdel Latef and Abu Alhmad (2013) in broad bean with copper stress. Supplementing the medium with $\mathrm{Ca}$ enhanced photosynthetic pigments in Vicia faba (Siddique et al., 2012) and Brassica juncea (Ahmad et al., 2015) under Cd toxicity. Ca served as secondary messenger for cytokinin action in improving synthesis of Chl (Lechowski and Bialczyk, 1993). K also plays a remarkable role in development of photosynthetic pigments by preventing degradation of newly formed $\mathrm{Chl}$ and aminolevulinic acid (ALA) (Siddique et al., 2012). Song et al. (2015) also reported that application of $\mathrm{K}$ enhanced the photosynthetic efficiency by increasing chlorophyll content in zinc stressed $P$. persica. Thus, the improvements in photosynthetic pigments are due to the combined effect of $\mathrm{Ca}$ and $\mathrm{K}$ that provides tolerance to $C$. arietinum plants against $\mathrm{Cd}$ stress (Figure 3 ).

Pro accumulation under $\mathrm{Cd}$ exposure appears to be prevalent among plants (Zhao, 2011; Siddique et al., 2012; El-Beltagi and Mohamed, 2013). Pro plays a pivotal role in protection of plants from abiotic and biotic stresses (Ahmad et al., 2010, 2011, 2012a,b, 2014, 2015; Siddique et al., 2012; Abdel Latef and Tran, 2016). The possible roles of Pro in heavy metals toxicity can be due to (i) its ability to balance the plant water potential (Fariduddin et al., 2009), (ii) its ability to save enzymes from inhibition (Sharma and Dietz, 2006), (iii) its function as metal chelator (Sharma et al., 1998), and (v) its antioxidant property (Zhao, 2011). The accumulation of protein during heavy metal stress may furnish a reserve form of $\mathrm{N}$ that could be reutilized later and helps in osmoregulation. The greater increase in protein content under Cd stress was followed by a significant decline in growth. Thus, it may be suggested that under these conditions, C. arietinum transfer most of the synthesized protein from a state of growth to a state of osmoregulation (survival). Thus, C. arietinum under Cd stress synthesized the protein for survival rather than for growth. However, application of $\mathrm{Ca}$ and $\mathrm{K}$ together was found to be efficient for augmenting further accumulation of Pro and protein under Cd stress. Ca signaling is involved in Probiosynthesis (Verslues and Sharma, 2010). Calmodulin, a Ca signaling unit has been reported to activate MYB (myeloblastosis) transcription factor which further activates different downstream genes including $\Delta^{1}$ pyrroline-5-carboxlyate synthetase 1 (P5CS1) (Yoo et al., 2005). Phospholipase " $\mathrm{C}$ " is another calcium signaling component which upregulated the expression of P5CS1 gene in Arabidopsis under salt stress (Parre et al., 2007). The Pro biosynthesis occurs through the activation of the precursors like glutemic acid, arginine and ornithine (Stewart and Bogess, 1977) and N-acetyl gutamic acid (Morris et al., 1969). K has the ability to interact with arginine in synergistic way enhancing the Pro content (Nageswararao et al., 1981). The accumulation of protein by application of $\mathrm{Ca}$ in the present study is in accordance with Abdel Latef (2011a) in canola plants under seawater stress. Recently, Yousuf et al. (2015) also reported that, application of $\mathrm{K}$ and $\mathrm{Ca}$ fertilizers regained the protein content in salt-stressed Indian mustard. K supplementation also enhanced the protein content in salt stressed wheat plants (Zheng et al., 2008). K has a leading role in plant protein synthesis (Blevins, 1985). The role of Ca and $\mathrm{K}$ in enhancing protein content may also be attributed to enhanced protein synthesis, decreased proteolysis, lowering of enzyme denaturation that were disturbed during abiotic stress (Levitt, 1980).

The decrease in total phenols and flavonoids content subjected to $\mathrm{Cd}$ stress is corroborated with the findings of Kapoor et al. (2014). Lachman et al. (2005) also reported the decrease in flavonoids content with increasing concentration of $\mathrm{Cd}$ in barley. Bai et al. (2004) reported that flavonoids play a great role in metal chelation. The increase in $\mathrm{Cd}$ content decreased the free flavonoids content in the present study. Low concentration of Cd stress increases the flavonoids content in many plants; however, at higher concentrations a decrease was observed (Cetin et al., 2014) as also observed in present 
study. Phenolic compounds played a key role in protecting the plants against toxic effects induced by different stresses. Total phenols and flavonoids have the antioxidant property because they are electron-donating agents (Michalak, 2006), thus scavenge ROS. Phenolic compounds are synthesized quickly after stress exposure through the signaling processes (Bais et al., 2002; Li et al., 2005). Application of $\mathrm{Ca}$ and $\mathrm{K}$ increased the total phenols and flavonoids content under Cd stress (Figure 3). The mechanism underlying previous process is still unclear. However, $\mathrm{Ca}$ and $\mathrm{K}$-mediated increase the total phenols and flavonoids can be possible since: (i) $\mathrm{Ca}$ and $\mathrm{K}$ hamper the uptake of $\mathrm{Cd}$ as described above, (ii) $\mathrm{Ca}$ has a role in signaling and helps in upregulation of respective genes for polyphenols biosynthesis (Xu et al., 2014), and (iii) the reduced $\mathrm{Cd}$ in the cells has the ability to stimulate the phenylalanine ammonia lyase (PAL) enzyme activity, an important enzyme in phenylpropanoid biosynthesis (Kuthanova et al., 2004).

$\mathrm{H}_{2} \mathrm{O}_{2}$ production is very harmful for many biochemical reactions; however, it also plays a signaling role in plant growth and development (Mazid et al., 2011). $\mathrm{H}_{2} \mathrm{O}_{2}$ also interferes with the Calvin cycle that finally leads to decreased rate of photosynthesis (Hussain et al., 2013) and is usually proclaimed stress criterion in plants (Mourato et al., 2012). Cd stress causes lipid peroxidation and is a result of oxidative stress (Abdel Latef, 2013). MDA is the end product of peroxidation of lipid membranes and its concentration is ordinarily considered as a general criterion of lipid peroxidation as well as the stress level (Shamsi et al., 2008; Abdel Latef, 2011a, 2013; Ahmad et al., 2015; Anjum et al., 2015). Cd stress induced the production of ROS resulting in malfunctioning of biomolecules (Ahmad et al., 2015, 2016a). Cd-induced loss of membrane permeability, coupled with increased MDA production, has also been observed by Abdel Latef (2013) in pepper (Capsicum annuum) and Hussain et al. (2013) in Zea mays seedlings. Our results are also in agreement with findings of $\mathrm{Li}$ et al. (2016) who reported Cdinduced oxidative stress via an enhanced production of $\mathrm{H}_{2} \mathrm{O}_{2}$ and MDA contents in Arabidopsis. However, the Cd stressed plants that were subjected to $\mathrm{Ca}$ and $\mathrm{K}$ alone as well as in combination, showed less accumulation of $\mathrm{H}_{2} \mathrm{O}_{2}$ and MDA content (Figure 3). This might be due to the activity of antioxidant enzymes and Pro accumulation which have an adaptive significance, because of their role in detoxification of free radicals thus reducing oxidative damage to membranes under Cd stress (Siddique et al., 2012; Li et al., 2016). Talukdar (2012) reported that mitigation of Cd-induced stress by $\mathrm{Ca}$ application was due to decline in the levels of $\mathrm{H}_{2} \mathrm{O}_{2}$ accumulation and consequently protects the membranes from oxidative damage. Li et al. (2016) reported that Ca protection against $\mathrm{Cd}$-induced oxidative injuries is achieved through avoidance of $\mathrm{H}_{2} \mathrm{O}_{2}$ generation as well as the reduction of $\mathrm{Cd}$ uptake. Ca binds to the membrane phospholoipids thus stabilizing the lipid bilayer and providing the structural integrity (Hirschi, 2004; Yousuf et al., 2015) and is exhibited by the reduced MDA content in the plants treated with $\mathrm{Ca}$ (Siddique et al., 2012; Talukdar, 2012; Li et al., 2016). K plays an active role in reducing ROS production by decreasing the activity of $\mathrm{NAD}(\mathrm{P}) \mathrm{H}$ oxidases and maintaining photosynthetic electron transport (Cakmak, 2005; Siddique et al., 2012).
Plants synthesize numerous antioxidant enzymes as defense mechanism to cope with the oxidative stress (Foyer and Shigeoka, 2011). The antioxidant enzymes such as SOD, CAT, APX and GR are important components for preventing the oxidative stress in plants ( $\mathrm{Li}$ et al., 2016). SOD is the first line of defense that catalyzes the dismutation of $\mathrm{O}_{2}^{\bullet-}$ radicals to $\mathrm{H}_{2} \mathrm{O}_{2}$ and $\mathrm{O}_{2}$ (Alscher et al., 2002; Mourato et al., 2012). $\mathrm{H}_{2} \mathrm{O}_{2}$ is also toxic to plant cells and CAT carries out its decomposition to water and oxygen (Ahmad et al., 2015). APX showed much attraction toward $\mathrm{H}_{2} \mathrm{O}_{2}$ as compared to CAT, advocating that they have different roles in ROS detoxification. CAT is accountable for the elimination of surplus $\mathrm{H}_{2} \mathrm{O}_{2}$ and APX is labile for maintaining lower concentrations of $\mathrm{H}_{2} \mathrm{O}_{2}$ (Mittler, 2002; Mourato et al., 2012). GR is important in maintaining the pool of reduced glutathione by $\mathrm{H}_{2} \mathrm{O}_{2}$ removal and by activating the ascorbateglutathione cycle (Asada, 1999; Abdel Latef, 2011b). In this work, antioxidant enzymes (SOD, CAT, APX, and GR) increased markedly under Cd stress. The increase in antioxidant enzyme activity might be due to the overproduction of $\mathrm{H}_{2} \mathrm{O}_{2}$, which would produce oxidative damages in $\mathrm{Cd}$ stressed plants ( $\mathrm{Li}$ et al., 2016). The elevation in the activities of these enzymes showed that $C$. arietinum had the ability to acclimate Cd stress by developing an antioxidant defense system. In our work, GR was stimulated more than other antioxidant enzymes under $\mathrm{Cd}$ stress suggesting that $\mathrm{GR}$ is a major player in $\mathrm{H}_{2} \mathrm{O}_{2}$-scavenging in $\mathrm{Cd}$ stressed plants. An elevated activities of antioxidant enzymes and lower hydrogen peroxide and lipid peroxidation with $\mathrm{Ca}$ application suggested that $\mathrm{Ca}$ prevented the structural and functional deterioration of cell membranes (Abdel Latef, 2011a; Ahmad et al., 2015; Figure 3). Recent studies reported that application of $\mathrm{Ca}$ was found to be effective in enhancing the tolerance of plant to $\mathrm{Cd}$ stress by enhancing antioxidant systems (Siddique et al., 2012; Talukdar, 2012; El-Beltagi and Mohamed, 2013). The enhanced activity of antioxidant enzymes may also be due to the active role of $\mathrm{K}$, which activates more than 60 enzyme systems which aid in photosynthesis, regulate stomatal opening and nutrient-translocation, and enhancement in starch synthesis (Shamsi et al., 2008). Under stress, K also plays great role in protein synthesis, e.g., thioredoxin, glutaredoxin, cyclophilin which facilitate regeneration of the reduced form of peroxiredoxins participate in reducing the ROS formation in plants under biotic and abiotic stress (Tripathi et al., 2009; Siddique et al., 2012). Increases in the activities of all fourenzymes led to decrease in the level of both $\mathrm{H}_{2} \mathrm{O}_{2}$ and MDA content in response to application of $\mathrm{Ca}$ and $\mathrm{K}$. Consequently, this ensured recovery of plant growth by mitigating the oxidative damage induced by $\mathrm{Cd}$ treatment in chickpea plants (Figure 3).

Increased Cd concentration also decreased the uptake of mineral elements as reported by Gonçalves et al. (2009). The plant nutrients and $\mathrm{Cd}$ ions can compete for the same transporters; therefore, presence of $\mathrm{Cd}$ can result in mineral nutrients deficiency (Nazar et al., 2012; Figure 3). Rivelli et al. (2014) also reported that increasing concentration of Cd decreased the essential mineral uptake in sunflower. Exogenous application of $\mathrm{Ca}$ and $\mathrm{K}$ alleviated the negative effect of $\mathrm{Cd}$ on these nutrients in the present study (Figures 2A-D). Application 
of $\mathrm{Ca}$ and $\mathrm{K}$ might have decreased the $\mathrm{Cd}$-competition for the same transporter. Ca also blocks the entry of $\mathrm{Cd}$ in root through $\mathrm{Ca}$ channels, and controls the translocation of root-Cd to leaves. Thus, applied Ca to Cd-exposed plants can restore their transpiration and photosynthesis (Hayakawa et al., 2011).

\section{CONCLUSIONS}

It is inferred from the results of present work that exogenous application of $\mathrm{Ca}$ and/or $\mathrm{K}$ mitigated the negative effects of $\mathrm{Cd}$ on $C$. arietinum through osmoregulation, by adjusting the membrane stability, photosynthetic pigments and lowering $\mathrm{H}_{2} \mathrm{O}_{2}$ and MDA contents. Further, protection under $\mathrm{Cd}$ stress was achieved via improved activities of antioxidant enzymes such as SOD, CAT, APX, and GR. Supplementation of Ca and K improved the secondary metabolites that were suppressed by Cd-exposure. The study also confirmed $\mathrm{Cd}$-accrued decreases in the uptake of essential mineral elements and the crop yield. Contrarily, exogenously applied $\mathrm{Ca}$ and $\mathrm{K}$ improved the crop

\section{REFERENCES}

Abdel Latef, A. A. (2011a). Ameliorative effect of calcium chloride on growth, antioxidant enzymes, protein patterns and some metabolic activities of canola (Brassica napus L.) under seawater stress. J. Plant Nutr. 34, 1303-1320. doi: 10.1080/01904167.2011.580817

Abdel Latef, A. A. (2011b). Influence of arbuscular mycorrhizal fungi and copper on growth, accumulation of osmolyte, mineral nutrition and antioxidant enzyme activity of pepper (Capsicum annuum L.). Mycorrhiza 21, 495-503. doi: 10.1007/s00572-010-0360-0

Abdel Latef, A. A. (2013). Growth and some physiological activities of pepper (Capsicum annuum L.) in response to cadmium stress and mycorrhizal symbiosis. J. Agri. Sci. Tech. 15, 1437-1448.

Abdel Latef, A. A., and Abu Alhmad, M. F. (2013). Strategies of copper tolerance in root and shoot of broad bean (Vicia faba L.). Pak. J. Agri. Sci. 50, 323-328.

Abdel Latef, A. A., and Tran, L.-S. P. (2016). Impacts of priming with silicon on the growth and tolerance of maize plants to alkaline stress. Front. Plant Sci. 7:243. doi: 10.3389/fpls.2016.00243

Ahmad, P., Abd_Allah, E. F., Hashem, A., Sarwat, M., and Gucel, S. (2016a). Exogenous application of selenium mitigates cadmium toxicity in Brassica juncea L. (Czern \& Cross) by up-regulating antioxidative system and secondary metabolites. J. Plant Growth Regul. (in press). doi: 10.1007/s00344-016-9592-3

Ahmad, P., Abdel Latef, A. A., Hashem, A., Abd_Allah, E. F., Gucel, S., and Tran, L. S. P. (2016b). Nitric oxide mitigates salt stress by regulating levels of osmolytes and antioxidant enzymes in chickpea. Front. Plant Sci. 7:347. doi: 10.3389/fpls.2016.00347

Ahmad, P., Hakeem, K. R., Kumar, A., Ashraf, M., and Akram, N. A. (2012a). Salt-induced changes in photosynthetic activity and oxidative defense system of three cultivars of mustard (Brassica juncea L.). Afr. J. Biotechnol. 11, 2694-2703. doi: 10.5897/AJB11.3203

Ahmad, P., Jaleel, C. A., and Sharma, S. (2010). Antioxidative defence system, lipid peroxidation, proline metabolizing enzymes and biochemical activity in two genotypes of Morus alba L. subjected to $\mathrm{NaCl}$ stress. Russ. J. Plant Physiol. 57, 509-517. doi: 10.1134/S1021443710040084

Ahmad, P., Nabi, G., and Ashraf, M. (2011). Cadmium-induced oxidative damage in mustard [Brassica juncea (L.) Czern. \& Coss.] plants can be alleviated by salicylic acid. South Afr. J. Bot. 77, 36-44. doi: 10.1016/j.sajb.2010.05.003

Ahmad, P., Ozturk, M., and Gucel, S. (2012b). Oxidative damage and antioxidants induced by heavy metal stress in two cultivars of mustard (L) plants. Fres. Environ. Bull. 21, 2953-2961.

Ahmad, P., Ozturk, M., Sharma, S., and Gucel, S. (2014). Effect of sodium carbonate-induced salinity-alkalinity on some key osmoprotectants, yield through the enhancing uptake of mineral elements and the biosynthesis of photosynthetic pigments. Thus, application of mineral nutrients could be a strategy to improve the growth, development and economic yield in plants/crops growing in toxic metal-polluted soils.

\section{AUTHOR CONTRIBUTIONS}

$\mathrm{PA}, \mathrm{AA}, \mathrm{EA}$, and $\mathrm{AH}$ designed and performed the experimental work. PA, AA, EA, and AH have written the manuscript. MS, NAA and SG contributed in discussion part. MS and SG have done the statistical analysis, and formatting of the paper.

\section{ACKNOWLEDGMENTS}

The authors would like to extend their sincere appreciation to their institutions and acknowledges Deanship of Scientific Research at King Saud University for Funding the Research Group Project no RGP-271. protein profile, antioxidant enzymes, and lipid peroxidation in two mulberry (Morus alba L.) cultivars. J. Plant Interact. 9, 460-467. doi: 10.1080/17429145.2013.855271

Ahmad, P., Sarwat, M., Bhat, N. A., Wani, M. R., Kazi, A. G., and Tran, L. S. (2015). Alleviation of cadmium toxicity in Brassica juncea L. (Czern. \& Coss.) by calcium application involves various physiological and biochemical strategies. PLoS ONE 10:e0114571. doi: 10.1371/journal.pone. 0114571

Ahmad, P., Sarwat, M., and Sharma, S. (2008). Reactive oxygen species, antioxidants and signaling in plants. J. Plant Biol. 51, 167-173. doi: 10.1007/ BF03030694

Ali Khan, M. A., and Siddhu, G. (2006). Phytotoxic effect of cadmium (Cd) on physiology of Urd bean [Vigna mungo (L.) Heeper]. Adv. Plant Sci. 19, 439-444.

Alscher, R. G., Erturk, N., and Heath, L. S. (2002). Role of superoxide dismutases (SODs) in controlling oxidative stress in plants. J. Exp. Bot. 53, 1331-1341. doi: 10.1093/jexbot/53.372.1331

Amirjani, M. R. (2012). Effects of cadmium on wheat growth and some physiological factors. Int. J. Soil. Eros. 2, 50-58.

Anjum, N. A., Gill, S. S., Umar, S., Ahmad, I., Duarte, A. C., and Pereira, E. (2012). Improving growth and productivity of oleiferous Brassicas under changing environment: significance of nitrogen and sulphur nutrition, and underlying mechanisms. Sci. World J. 2012:657808. doi: 10.1100/2012/ 657808

Anjum, N. A., Sofo, A., Scopa, A., Roychoudhury, A., Gill, S. S., Iqbal, M., et al. (2015). Lipids and proteins-major targets of oxidative modifications in abiotic stressed plants. Environ. Sci. Pollut. Res. 22, 4099-4121. doi: 10.1007/s11356014-3917-1

Asada, K. (1999). The water-water cycle in chloroplasts: scavenging of active oxygens and dissipation of excess photons. Annu. Rev. Plant Physiol. Plant Mol. Biol. 50, 601-639. doi: 10.1146/annurev.arplant.50.1.601

Asgher, M., Khan, M. I. R., Anjum, N. A., and Khan, N. A. (2015). Minimizing toxicity of cadmium in plants - role of plant growth regulators. Protoplasma 252, 399-413. doi: 10.1007/s00709-014-0710-4

Bai, Y., Song, F., Chen, M., Xing, J., Liu, Z., and Liu, S. (2004). Characterization of the rutin-metal complex by electrospray ionisation tandem mass spectrometry. Analytical Sci. 20, 1147-1151. doi: 10.2116/analsci.20.1147

Bais, H. P., Walker, T. S., Schweizer, H. P., and Vivanco, J. M. (2002). Root specific elicitation and antimicrobial activity of rosmarinic acid in hairy root cultures of Ocimum basilicum. Plant Physiol. Biochem. 40, 983-995. doi: 10.1016/S09819428(02)01460-2

Bates, L., Waldren, P. P., and Teare, J. D. (1973). Rapid determination of free proline of water stress studies. Plant Soil 39, 205-207. doi: 10.1007/BF00018060 
Blevins, D. G. (1985). "Role of potassium in protein metabolism in plants," in Potassium in Agriculture, ed R. D. Munson (Madison, WI: ASA-CSSA-SSSA), 413-424.

Bradford, M. M. (1976). A rapid and sensitive method for the quantization of microgram quantities of pro- tein using the principle of protein-dye binding. Anal. Biochem. 72, 248-259. doi: 10.1016/0003-2697(76)90527-3

Cakmak, I. (2005). The role of potassium in alleviating detrimental effects of abiotic stresses in plants. J. Plant Nutr. Soil Sci. 168, 521-530. doi: 10.1002/jpln.200420485

Carlberg, I., and Mannervik, B. (1985). Glutathione reductase. Methods Enzymol. 113, 484-490. doi: 10.1016/S0076-6879(85)13062-4

Cetin, E. S., Babalik, Z., Hallac-Turk, F., and Gokturk-Baydar, N. (2014). The effects of cadmium chloride on secondary metabolite production in Vitis vinifera cv. cell suspension cultures. Biol. Res. 47:47. doi: 10.1186/0717-628747-47

Choi, Y. E., Harada, E., Wada, M., Tsuboi, H., Mortia, Y., Kusano, T., et al. (2001). Detoxification of cadmium in tobacco plant: formation and active excretion of crystals containing cadmium and calcium through trichomes. Planta 213, 45-50. doi: 10.1007/s004250000487

Chun, O. K., Kim, D. O., and Lee, C. Y. (2003). Superoxide radical scavenging activity of the major polyphenols in fresh plums. J. Agricul. Food Chem. 51, 8067-8072. doi: 10.1021/jf034740d

Clarkson, D. T., and Luttge, U. (1989). Mineral nutrition. Divalent cations, transport and compartmentalization. Prog. Bot. 51, 93-112. doi: 10.1007/9783-642-75154-7_7

Dinakar, N., Nagajyothi, P. C., Suresh, S., Damodharam, T., and Suresh, C. (2009). Cadmium induced changes on proline, antioxidant enzymes, nitrate and nitrite reductases in Arachis hypogaea L. J. Environ. Biol. 30, 289-294.

Dong, J., Wu, F., and Zhang, G. (2005). Effect of cadmium on growth and photosynthesis of tomato seedlings. Zhejiang Univ. Sci. B. 6, 974-980. doi: 10.1631/jzus.2005.B0974

El-Beltagi, H. S., and Mohamed, H. I. (2013). Alleviation of cadmium toxicity in Pisum sativum L. seedlings by calcium chloride. Not. Bot. Horti. Agrobo. 41, $157-168$.

Eller, F., and Brix, H. (2016). Influence of low calcium avaliability on cadmium uptake and translocation in a fast-growing shrub and a metal accumulating herb. AOB Plant. 8:plv143.

Fariduddin, Q., Khanam, S., Hasan, S. A., Ali, B., Hayat, S., and Ahmad, A. (2009). Effect of 28-homobrassinolide on the drought stress-induced changes in photosynthesis and antioxidant system of Brassica juncea L. Acta Physiol. Plant. 31, 889-897. doi: 10.1007/s11738-009-0302-7

Fatoba, P. O., Ogunkunle, C. O., and Salihu, B. Z. (2012). Toxic effects of cadmium $(\mathrm{Cd})$ and Lead $(\mathrm{Pb})$ on growth and productivity of Arachis hypogaea $(\mathrm{L})$ and Glycine max (L). J. Asian Sci. Res. 2, 254-259.

Foyer, C. H., and Shigeoka, S. (2011). Understanding oxidative stress and antioxidant functions to enhance photosynthesis. Plant Physiol. 155, 93-100. doi: 10.1104/pp.110.166181

Gonçalves, J. F., Antes, F. G., Maldaner, J., Pereira, L. B., Tabaldi, L. A., Rauber, R., et al. (2009). Cadmium and mineral nutrient accumulation in potato plantlets grown under cadmium stress in two different experimental culture conditions. Plant Physiol. Biochem. 47, 814-821. doi: 10.1016/j.plaphy.2009.04.002

Hasanuzzaman, M., and Fujita, M. (2011). Selenium pretreatment upregulates the antioxidant defense and methylglyoxal detoxification system and confers enhanced tolerance to drought stress in rapeseed seedlings. Biol. Trace Elem. Res. 143, 1758-1776. doi: 10.1007/s12011-011-8998-9

Hasanuzzaman, M., and Fujita, M. (2013). Exogenous sodium nitroprusside alleviates arsenic-induced oxidative stress in wheat (Triticum aestivum L.) seedlings by enhancing antioxidant defense and glyoxalase system. Ecotoxicol. 22, 584-596. doi: 10.1007/s10646-013-1050-4

Hayakawa, N., Tomioka, R., and Takenaka, C. (2011). Effects of calcium on cadmium uptake and transport in the tree species Gamblea innovans. Soil Sci. Plant Nutr. 57, 691-695. doi: 10.1080/00380768.2011.608196

Heath, R. L., and Packer, L. (1968). Photoperoxidation in isolated chloroplasts. I. Kinetics and stoichiometry of fatty acid peroxidation. Arch. Biochem. Biophy. 125, 189-198. doi: 10.1016/0003-9861(68)90654-1

Hernandez, J. A., and Almansa, M. S. (2002). Short term effects of salt stress on antioxidant systems and leaf water relations of pea leaves. Physiol Plant. 115, 251-257. doi: 10.1034/j.1399-3054.2002.1150211.x
Hinkle, P. M., Kinsella, P. A., and Osterhoudt, K. C. (1987). Cadmium uptake and toxicity via voltage-sensitive calcium channels. J. Biol. Chem. 262, 16333-16337.

Hirschi, K. D. (2004). The calcium conundrum. both versatile nutrient and specific signal. Plant Physiol. 136, 2438-2442. doi: 10.1104/pp.104.046490

Hiscox, J. D., and Israelstam, G. F. (1979). A method for the extraction of chlorophyll from leaf tissue without maceration. Can. J. Bot. 57, 1332-1334. doi: 10.1139/b79-163

Hussain, I., Akhtar, S., Ashraf, M. A., Rasheed, R., Siddiqi, E. H., and Ibrahim, M. (2013). Response of maize seedlings to cadmium application after different time intervals. Agronomy 2013:169610. doi: 10.1155/2013/169610

Ismail, M. A. (2008). Involvement of $\mathrm{Ca}^{2+}$ in alleviation of $\mathrm{Cd}^{2+}$ toxicity in common bean (Phaseolus vulgaris L.) plants. Res. J. Agric. Biol. Sci. 4, 203-209.

Kapoor, D., Kaur, S., and Bhardwaj, R. (2014). Physiological and biochemical changes in Brassica juncea Plants under Cd-induced stress. Biomed Res. Int. 2014:726070. doi: 10.1155/2014/726070

Khan, N. A., Nazar, R., Iqbal, N., and Anjum, N. A. (2012). Phytohormones and Abiotic stress Tolerance in Plants. Berlin; Heidelberg: Springer.

Kinraide, T. B. (1998). Three mechanisms for the calcium alleviation of mineral toxicities. Plant Physiol. 118, 513-520. doi: 10.1104/pp.118.2.513

Kumar, S., and Dhingra, H. R. (2005). Sexual reproduction and cadmium partitioning in two mungbean genotypes raised in soils contaminated with cadmium. Ind. J. Plant Physiol. 10, 151-157.

Kuthanova, A., Gemperlova, L., Zelenkova, S., Eder, J., Machackovai Opatrny, Z., and Cvikrova, M. (2004). Cytological changes and alterations in polyamine contents induced by cadmium in tobacco BY-2 cells. Plant Physiol. Biochem. 42, 149-156. doi: 10.1016/j.plaphy.2003.11.003

Lachman, J., Dudjak, J., Miholová, D., Kolihová, D., and Pivec, V. (2005). Effect of cadmium on flavonoid content in young barley (Hordeum sativum L.) plants. Plant Soil Environ. 51, 513-516.

Lechowski, Z., and Bialczyk, J. (1993). Calcium mediated cytokinin action on chlorophyll synthesis in isolated embryo of Scots pine. Biol. Plant. 35, 53-62. doi: 10.1007/BF02921119

Levitt, J. (1980). Responses of Plant to Environmental Stresses. Water, Radiation, Salt and Other Stresses. New York, NY: Academic Press.

Li, W., Koike, K., Asada, Y., Yoshikawa, T., and Nikaido, T. (2005). Rosmarinic acid production by Coleus forskohlii hairy root cultures. Plant Cell Tiss. Org. 80, 151-155. doi: 10.1007/s11240-004-9541-X

Li, P., Zhao, C., Zhang, Y., Wang, X., Wang, X., Wang, J., et al. (2016). Calcium alleviates cadmium-induced inhibition on root growth by maintaining auxin homeostasis in Arabidopsis seedlings. Protoplasma 253, 185-200. doi: 10.1007/ s00709-015-0810-9

Luck, H. (1974). “Catalase," in Methods of Enzymatic Analysis, Vol. II, eds J. Bergmeyer and M. Grabi (New York, NY: Academic Press), 885-890.

Mazid, M., Khan, T. A., and Mohammad, F. (2011). Potential of $\mathrm{NO}$ and $\mathrm{H}_{2} \mathrm{O}_{2}$ as signaling molecules in tolerance to abiotic stress in plants. J. Indus. Res. Technol. $1,56-68$.

Mengel, K. (2007). “Potassium," in Handbook of Plant Nutrition, eds A. V. Barker and D. J. Pilbeam (Boca Raton, FL: CRC Press), 91-120.

Michalak, A. (2006). Phenolic compounds and their antioxidant activity in plants growing under heavy metal stress. Polish J. Environ. Stud. 15, 523-530.

Mittler, R. (2002). Oxidative stress, antioxidants and stress tolerance. Trend. Plant Sci. 7, 405-410. doi: 10.1016/S1360-1385(02)02312-9

Mobin, M., and Khan, N. A. (2007). Photosynthetic activity, pigment composition and antioxidative response of two mustard (Brassica juncea) cultivars differing in photosynthetic capacity subjected to cadmium stress. J. Plant Physiol. 164, 601-610. doi: 10.1016/j.jplph.2006.03.003

Mondal, N. K. (2013). Effect of varying cadmium stress on chickpea (Cicer arietinum L.) seedlings: an ultrastructural study. Ann. Environ. Sci. 7, 59-70.

Morris, C. J., Thompson, J. F., and Johnson, C. M. (1969). Metabolism of glutamic acid and $\mathrm{N}$-acetylglutamic acid in leaf discs and cell-free extracts of higher plants. Plant Physiol. 44, 1023-1026. doi: 10.1104/pp.44.7.1023

Mourato, M., Reis, R., and Martins, L. L. (2012). "Characterization of plant antioxidative system in response to abiotic stresses," in A Focus on Heavy Metal Toxicity, Advances in Selected Plant Physiology Aspects, ed G. Montanaro (Rijeka: InTech), 23-44.

Nageswararao, R. C., Krishnasastry, K. S., and Udayakumar, M. (1981). Role of potassium in proline metabolism. i. conversion of precursors into proline under 
stress conditions in K-sufficient and K-deficient plants. Plant Sci. Lett. 23, 327-334. doi: 10.1016/0304-4211(81)90044-4

Nakano, Y., and Asada, K. (1981). Hydrogen peroxide is scavenged by ascorbatespecific peroxidase in spinach chloroplasts. Plant Cell Physiol. 22, 867-880.

Nazar, R., Iqbal, N., Masood, A., Khan, M. I. R., Syeed, S., and Khan, N. A. (2012). Cadmium toxicity in plants and role of mineral nutrients in its alleviation. Am. J. Plant Sci. 3, 1476-1489. doi: 10.4236/ajps.2012.310178

Noraho, N., and Gaur, J. P. (1995). Effect of cations, including heavy metals, on cadmium uptake by Lemna polyrhiza L. Biometal 8, 95-98. doi: 10.1007/BF00142006

Parre, E., Ghars, M. A., Leprince, A. S., Thiery, L., Lefebvre, D., Bor- denave, M., et al. (2007). Calcium signaling via phospholipase C is essential for proline accumulation upon ionic but not nonionic hyperosmotic stresses in Arabidopsis. Plant Physiol. 144, 503-512. doi: 10.1104/pp.106.095281

Perfus-Barbeoch, L., Leonhardt, N., Vavasseur, A., and Forestier, C. (2002). Heavy metal toxicity: cadmium permeates through calcium channels and disturbs the plant water status. Plant J. 32, 539-548. doi: 10.1046/j.1365-313X.2002.01442.x

Rasool, S., Ahmad, A., Siddiqi, T. O., and Ahmad, P. (2013). Changes in growth, lipid peroxidation and some key antioxidant enzymes in chickpea genotypes under salt stress. Acta Physiol. Plant. 35, 1039-1050. doi: 10.1007/s11738-0121142-4

Rasool, S., Ahmad, P., Rehman, M., Arif, A., and Anjum, N. A. (2015). Achieving crop stress tolerance and improvement-an overview of genomic techniques. Appl. Biochem. Biotechnol. 177, 1395-1408. doi: 10.1007/s12010-015-1830-9

Rivelli, A. R., Puschenreiter, M., and De Maria, S. (2014). Assessment of cadmium uptake and nutrient content in sunflower plants grown under Cd stress. Plant Soil Environ. 60, 80-86.

Rivetta, A., Negrini, N., and Cocucci, M. (1997). Involvement of $\mathrm{Ca}^{2+}$-calmodulin in $\mathrm{Cd}^{2+}$ toxicity during the early phases of radish (Raphanus sativus L.) seed germination. Plant Cell Environ. 20, 600-608. doi: 10.1111/j.13653040.1997.00072.x

Sandalio, L. M., Dalurzo, H. C., Gómez, M., Romero-Puertas, M. C., and del Rio, L. A. (2001). Cadmium-induced changes in the growth and oxidative metabolism of pea plants. J. Exp. Bot. 52, 2115-2126.

Shamsi, I. H., Jilani, G., Zhang, G. P., and Kang, W. (2008). Cadmium stress tolerance through potassium nutrition in soybean. Asian J. Chem. 20, 1099-1108.

Sharma, S. S., and Dietz, K. J. (2006). The significance of amino acids and amino acid-derived molecules in plant responses and adaptation to heavy metal stress. J. Exp. Bot. 57, 711-726. doi: 10.1093/jxb/erj073

Sharma, S. S., Schat, H., and Vooijs, R. (1998). In vitro alleviation of heavy metal induced enzyme inhibition by proline. Phytochem. 46, 1531-1535. doi: 10.1016/S0031-9422(98)00282-9

Siddhu, G., and Khan, M. A. A. (2012). Effects of cadmium on growth and metabolism of Phaseolus mungo. J. Environ. Biol. 3, 173-179.

Siddique, M. H., Al-Whaibi, M. H., Sakran, A. H., Basalah, M. O., and Ali, H. M. (2012). Effect of calcium and potassium on antioxidant system of Vicia faba L. under cadmium stress. Int. J. Mol. Sci. 13, 6604-6619. doi: 10.3390/ijms13066604

Song, W. Y., Martinoia, E., Lee, J., Kim, D., Kim, D. Y., Vogt, E., et al. (2004). A novel family of cys-rich membrane proteins mediates cadmium resistance in Arabidopsis. Plant Physiol. 135, 1027-1039. doi: 10.1104/pp.103.037739

Song, Z. Z., Duan, C. L., Guo, S. L., Yang, Y., Feng, Y. F., Ma, R. J., et al. (2015). Potassium contributes to zinc stress tolerance in peach (Prunus persica) seedlings by enhancing photosynthesis and the antioxidant defense system. Genet. Mol. Res. 14, 8338-8835. doi: 10.4238/2015.July.27.22

Stewart, C. R., and Bogess, S. F. (1977). The effect of wilting on the conversion of arginine, ornithine, and glutamate to proline in bean leaves. Plant Sci. Lett. 8, 147-153. doi: 10.1016/0304-4211(77)90025-6

Suzuki, N. (2005). Alleviation by calcium of cadmium-induced root growth inhibition in Arabidopsis seedlings. Plant Biotechnol. 22, 19-25. doi: 10.5511/plantbiotechnology.22.19

Suzuki, N., Yamaguchi, Y., Koizumi, N., and Sano, H. (2002). Functional characterization of a heavy metal binding protein Cdl19 from Arabidopsis. Plant J. 32, 165-173. doi: 10.1046/j.1365-313X.2002.01412.x
Talukdar, D. (2012). Exogenous calcium alleviates the impact of cadmiuminduced oxidative stress in Lens culinaris Medic. seedlings through modulation of antioxidant enzyme activities. J. Crop Sci. Biotechnol. 15, 325-334. doi: 10.1007/s12892-012-0065-3

Tripathi, B. N., Bhatt, I., and Dietz, K. J. (2009). Peroxiredoxins: a less studied component of hydrogen peroxide detoxification in photosynthetic organisms. Protoplasma 235, 3-15. doi: 10.1007/s00709-009-0032-0

Van Rossum, M. W. P. C., Alberda, M., and Van der Plas, L. H. W. (1997). Role of oxidative damage in tulip bulb scale micropropagation. Plant Sci. 130, 207-216. doi: 10.1016/S0168-9452(97)00215-X

Velikova, V., Yordanov, I., and Edreva, A. (2000). Oxidative stress and some antioxidant systems in acid rain-treated bean plants. Protective role of exogenous polyamines. Plant Sci. 151, 59-66. doi: 10.1016/S01689452(99)00197-1

Verslues, P. E., and Sharma, S. (2010). Proline metabolism and its implications for plant-environment interaction. Arabidopsis Book. 8:e0140. doi: 10.1199/tab.0140

Weng, X. Y., Zheng, C. J., Xu, H. X., and Sun, J. Y. (2007). Characteristics of photosynthesis and functions of the water-water cycle in rice (Oryza sativa) leaves in response to potassium deficiency. Physiol. Plant. 131, 614-621. doi: 10.1111/j.1399-3054.2007.00978.x

White, P. J. (2000). Calcium channels in higher plants. Biochem. Biophys. Acta 1465, 171-189. doi: 10.1016/S0005-2736(00)00137-1

Xu, W., Peng, H., Yang, T., Whitaker, B., Huang, L., Sun, J., et al. (2014). Effect of calcium on strawberry fruit flavonoid pathway gene expression and anthocyanin accumulation. Plant Physiol. Biochem. 82, 289-298. doi: 10.1016/j.plaphy.2014.06.015

Yoo, R. H., Park, C. Y., Kim, J. C., Heo, W. D., Cheong, M. S., Park, H. C., et al. (2005). Direct interaction of a divergent CaM isoform and the transcription factor, MYB2, enhances salt tolerance in Arabidopsis. J. Biol. Chem. 280, 3697-3706. doi: 10.1074/jbc.M408237200

Yousuf, P. Y., Ahmad, A., Hemant Ganie, A. H., Aref, I. M., and Iqbal, M. (2015). Potassium and calcium application ameliorates growth and oxidative homeostasis in salt-stressed indian mustard (Brassica juncea) Plants. Pak. J. Bot. 47, 1629-1639.

Zhao, Y. (2011). Cadmium accumulation and antioxidative defenses in leaves of Triticum aestivum L. and Zea mays L. Afr. J. Biotechnol. 10, 2936-2943.

Zhao, Z. Q., Zhu, Y. G., Li, H. Y., Smith, S. E., and Smith, F. A. (2003). Effects of forms and rates of potassium fertilizers on cadmium uptake by two cultivars of spring wheat (Triticum aestivum L.). Environ. Intern. 29, 973-978. doi: 10.1016/S0160-4120(03)00081-3

Zheng, Y., Jia, A., Ning, T., Xu, J., Li, Z., and Jiang, G. (2008). Potassium nitrate application alleviates sodium chloride stress in winter wheat cultivars differing in salt tolerance. J. Plant Physiol. 165, 1455-1465. doi: 10.1016/j.jplph.2008.01.001

Zhishen, J., Mengcheng, T., and Jianming, W. (1999). The determination of flavonoid contents in mulberry and their scavenging effects on superoxide radicals. Food Chem. 64, 555-559. doi: 10.1016/S0308-8146(98) 00102-2

Zorb, C., Senbayramb, M., and Peiter, E. (2014). Potassium in agriculture - status and perspectives. J. Plant Physiol. 171, 656-669. doi: 10.1016/j.jplph.2013.08.008

Conflict of Interest Statement: The authors declare that the research was conducted in the absence of any commercial or financial relationships that could be construed as a potential conflict of interest.

Copyright (c) 2016 Ahmad, Abdel Latef, Abd_Allah, Hashem, Sarwat, Anjum and Gucel. This is an open-access article distributed under the terms of the Creative Commons Attribution License (CC BY). The use, distribution or reproduction in other forums is permitted, provided the original author(s) or licensor are credited and that the original publication in this journal is cited, in accordance with accepted academic practice. No use, distribution or reproduction is permitted which does not comply with these terms. 